\title{
White sponge nevus
}

INSERM

\section{Source}

INSERM. (1999). Orphanet: an online rare disease and orphan drug data base. White sponge nevus. ORPHA:171723

White sponge nevus (WSN) is a rare and autosomal dominant genetic disease in which the oral mucosa is white or greyish, thickened, folded, and spongy. The onset is early in life, and both sexes are affected equally. Other common sites include the tongue, floor of the mouth, and alveolar mucosa. 